\title{
Aleksandra Krzyżanowska, Michał Gawlikowski. Monnaies des fouilles polonaises à Palmyre
}

\section{Rika Gyselen}

\section{Q OpenEdition}

1 Journals

\section{Édition électronique}

URL : http://journals.openedition.org/abstractairanica/42631

DOI : 10.4000/abstractairanica.42631

ISBN : 1961-960X

ISSN : 1961-960X

Éditeur :

CNRS (UMR 7528 Mondes iraniens et indiens), Éditions de l'IFRI

Référence électronique

Rika Gyselen, «Aleksandra Krzyżanowska, Michał Gawlikowski. Monnaies des fouilles polonaises à Palmyre », Abstracta Iranica [En ligne], Volume 37-38-39 | 2018, document 8, mis en ligne le 10 mars 2018, consulté le 28 septembre 2020. URL : http://journals.openedition.org/abstractairanica/42631 DOI : https://doi.org/10.4000/abstractairanica.42631

Ce document a été généré automatiquement le 28 septembre 2020

Tous droits réservés 


\section{Aleksandra Krzyżanowska, Michał Gawlikowski. Monnaies des fouilles polonaises à Palmyre}

Rika Gyselen 


\section{RÉFÉRENCE}

Aleksandra Krzyżanowska, Michał Gawlikowski. Monnaies des fouilles polonaises à Palmyre, Studia Palmyreńskie XIII, Polish Centre of Mediterranean Archaeology, University of Warsaw, 2014. 140 p. ISBN 978-83-235-1607-1

1 Cet ouvrage est consacré aux monnaies trouvées entre 1959 et 2001 lors des fouilles polonaises à Palmyre. Le premier volet comporte essentiellement des monnaies hellénistiques et romaines (A. Krzyżanowska), le deuxième des monnaies sassanides et arabo-sassanides (M. Gawlikowski). Ces dernières font partie d'un trésor monétaire trouvé en 2001: d'une part une bourse en tissu contenant environ 708 monnaies et d'autre part 18 monnaies agglutinées à proximité. 694 monnaies sont des émissions des rois sassanides (de Kawād Ier à Yazdgerd III), 32 monnaies sont arabo-sassanides. Beaucoup de monnaies sont fragmentaires, ou trop corrodées pour pouvoir être lues complètement. La plus ancienne monnaie date de l'an 15 du règne de Kawād Ier ( \pm 514 $\mathrm{AD})$ et la plus récente $76 \mathrm{H}(669 \mathrm{AD})$. Cinq monnaies portent des inscriptions en surcharge incisées et une un graffito à l'encre.

Chaque monnaie a été cataloguée avec les informations nécessaires pour ce type de monnayage et les monnaies les mieux conservées sont illustrées. Les index par année de règne et par atelier sont présentés sous forme de tableaux dans le texte. S'y ajoutent des observations sur quelques ateliers monétaires. L'atelier qui a été lu TLWKWALT (p. 78, II.80) a entretemps fait l'objet d'une petite note (R. Gyselen, « Toponymes sassanides composés avec le terme moyen-perse win(n)ärd ", Studia Iranica, 42, 2013, 2, p. 277-281) dans laquelle est proposée la lecture MLWWNALT et l'interprétation Marw-winnārd.

\section{AUTEURS}

\section{RIKA GYSELEN}

CNRS, Mondes iranien et indien 